\title{
Метафорический концепт «Путь» в творчестве П.А. Сорокина
}

\author{
Ревво Ю.А., соискатель, \\ Технический институт (филиал) \\ Северо-Восточного федерального университета, \\ 2. Нерюнгри \\ E-mail: juliarevvo@mail.ru
}

Научный руководитель: к.филол.н. Павлова Т.Л.

Семантика метафорических концептов «Путь»в автобиографической повести П.А. Сорокина «Дальняя дорога»рассматривается автобиографическое произведение выдающегося социолога и писателя.По словам автора, «это книга-памятник, книгареквием»[Сорокин П. Дальняя дорога. М.: Терра, 1992. С. 6.].

Под «памятником» в данном случае подразумевается памятник дням былым, той России, которую покинул автор, ставший после Октябрьской революции и Гражданской войны эмигрантом. «Реквием» - это траур по навсегда ушедшей России и тем, кто не пережил страшных дней смуты и междоусобиц.

П.А. Сорокин был выслан за границу по постановлению Коллегии ГПУ от 26 сентября 1922 г. Сорокин покинул родину на том самом «философским пароходе», на котором, по приказанию В.И. Ленина, уехали из Советской России выдающиеся философы и ученые.

Странствия, скитания - рефрен воспоминаний П. Сорокина, непосредственно связанный со смысловой парадигмой метафорического концепта «Путь». Однако любой земной путь предполагает наличие конечного пункта, места назначения. В произведении П.А. Сорокина такого конечного пункта нет. Дальняя дорога - это символ дороги в вечность.

В. Липский, автор предисловия к американскому изданию «Дальней дороги», так трактует выбор названия: «Возьмем в качестве примера английское название книги - "А Long Journey". (...) Наиболее вероятных, отвечающих замыслу и содержанию книги переводов названия - два: "Долгий путь"или "Дальняя дорога". Какой из них ближе авторскому оригиналу? (...) Смею надеяться - второй. Странствия, бродяжья жизнь перекати-поля, скитания - рефрен его воспоминаний - не сочетаются со словом "путь", семантически предполагающим, пусть и не явно, наличие некоего конечного пункта, места назначения. И, наоборот, дорога как modus vivendi, как образ жизни (via est vita), подходит для перевода наилучшим образом. (...) Вспомним образ дальней дороги в стихах другого российского интеллигента, можно сказать "внутреннего эмигранта", Булата Шалвовича Окуджавы:

...И дальняя дорога дана тебе судьбой,

как матушкины слезы, всегда она с тобой» [Сорокин П. Дальняя дорога. М.: Teppa, 1992. С. 6.].

В. Липский указывает в данном случае на «Песенку о дальней дороге» Б. Окуджавы, в которой есть такие строки: «Жена, как говорится, найдет себе другого, / Какого-никакого, как ты, недорогого. / А дальняя дорога дана тебе судьбой, / Как матушкины слезы, она всегда с тобой» [Окуджава Б. «Песенка о дальней дороге».Интернет-ресурс: $\quad$ http://libverse.ru/okydzhava/zabydesh-pozdnii-prazdnik-i- 
pervyiy-ytraty.html] В этом стихотворении Окуджавы дальняя дорога - это возможность отрешиться от страстей человеческих и воспарить духом.

Дальняя дорога и лунная ночь присутствуют и в русском романсе Б. Фомина и К. Подревского, исполнявшемся А. Вертинским: «Дорогой длинною»: «Дорогой длинною, да ночью лунною, / Да с песней той, что вдаль летит, звеня. / И с той старинною, да с семиструнною, / Что по ночам так мучила меня» [Мы жили тогда на планете другой...». Антология поэзии русского зарубежья в 4 т. 1920-1990. Т. 1. М.: Московский рабочий, 1995. С. 295.] Книга воспоминаний А. Вертинского озаглавлена «Дорогой длинною».

Связь между названием книги мемуаров писателя-эмигранта П.А. Сорокина «Дальняя дорога» и популярным среди русских эмигрантов Первой волны романсом «Дорогой длинною» очевидна. Романс «Дорогой длинною» был написан Б.Фоминым (музыка) и К. Подревским (слова) в 1924 г. и был необыкновенно популярен среди русских эмигрантов.

Дальняя жизненная дорога Питирима Сорокина начинается в мемуарах со сцены отпевания матери. Эпизод отпевания матери отсылает нас к сцене церковного погребения рано умершей матери пастернаковского Юрия Живаго. У П. Сорокина мы видим большую, воцерковленную семью, истово исполняющую православные обряды. У Пастернака Юрий Живаго, осиротевший после смерти матери и самоубийства отца, попадает в семью скорее интеллигентски-философствующую, чем воцерковленную. Однако то, что повествование и у Б. Пастернака, и у П. Сорокина начинается со смерти матери, очень символично. Образ-символ матери (матушки) связан с Вечной Женственностью, с богородичным началом мироздания, а ее смерть - это утрата богородичного начала, предчувствие грядущих «великих скорбей».

И у П.А. Сорокина в «Дальней дороге», и у М.А. Булгакова в «Белой гвардии» в сцене похорон матери доминирует белый цвет, символизирующий вечность, добродетель, чистоту. После белого цвета, связанного с темой Матери, с символикой Вечной Женственности, Сорокин вводит голубой, небесный цвет, цвет церковных куполов. Для Сорокина небесный голубой - цвет неба и веры, православной веры отцов. Третий цвет, введенный писателем в художественную ткань текста, - это зеленый, цвет церковных крыш, символизирующий вечную весну, сияние жизни.

Жизненная дорога П.А. Сорокина началась на Севере Руси, вЯренском уезде Вологодской губернии. Такое начало «Пути», понимаемого не только как физическое движение во времени и пространстве, но и как духовное странствие, самосовершенствование, постижение Бога и Вечности, более чем символично. Сорокин упоминает, что Яренский уезд Вологодской губернии - это край первозданных лесов, не оскверненных цивилизацией, край наполненной мудростью тишины. Мир детства, представленный читателю Питиримом Сорокиным, - это мир волшебный, сакральный, переносящий и читателя и повествователя в иное пространство, чистое и святое.

Смерть матери стала началом распада семьи Сорокиных. Более того, смерть матери превратила и отца, и сыновей в странников Божьих, лишила их дома и «теплого» семейного мира. В «Дальней дороге» мотив смерти матери напрямую связан с мотивом утраты дома.

Странствующим ремесленником (сапожником) был библейский Агасфер, Вечный Жид, наказанный вечными скитаниями за то, что не подал воды Спасителю, шедшему на Голгофу. Отец героя-рассказчика наказан за то, что поднял руку на своих 
детей. Его кара - это многолетние скитания вдали от дома и сыновей. Только после смерти отца дети восстанавливают в памяти чистый образ отца-мастера.

Если отец назван в «Дальней дороге» мастером, то юный Питирим первоначально играет по отношению к нему роль подмастерья. Отношения «Мастер Подмастерье» наполнены в «Дальней дороге» символическим смыслом. Отец героярассказчика (Мастер) занимается ремонтом и реставрацией православных храмов и их внутреннего убранства, тем самым приобщая сына (Подмастерье) к духовным ценностям православия. Разрыв с отцом будет обозначать постепенный отход героя от православных (шире - христианских) ценностей и превращение Подмастерья в «бродячего миссионера революции».

Профессия героя-рассказчика, его отца и братьев очень важна в мотивном и мифопоэтическом плане. Мастера, подобные герою-рассказчику, его отцу и братьям, являются творцами формы, они властвуют над материалом. Однако путь героярассказчика уводит его из мира мастеров, властвующих над формой и материалом, и приводит в мир «самозванных пророков» - революционеров.

Главы книги соответствуют смысловому наполнению концепта «Путь»: «Разъезды: встречи и расставания», «Бродячий миссионер революции», «Зайцем на поезде», «В бегах», «Возвращение к природе», «Высылка». Рассказывая о путяхдорогах своей юности, Питирим Сорокин вспоминает библейскую притчу о хлебе, брошенном в воду. Имеется в виду следующее изречение из Экклезиаста: «Отпускай хлеб твой по водам, потому что по прошествии многих дней опять найдешь его» (Еккл. 11:1).

В Древнем Израиле был такой обычай: люди опускали хлеб в воду, и он плыл по течению. Хлеб подбирали голодные и нуждающиеся. При этом подразумевалось, что и дающий может стать нуждающимся. Выражение «отпускай свой хлеб по водам» имеет двоякое значение: делать добрые дела и нести весть о спасении человеку в частности и человечеству в целом. Как известно, «Хлебом жизни» в Евангелиях назван Христос (« ... не хлебом одним будет жить человек, но всяким словом Божиим». Лук.4:4.; «Я есмь хлеб жизни; приходящий ко Мне не будет алкать, и верующий в Меня не будет жаждать никогда». Иоан. 6:35.; «Я хлеб живый, сшедший с небес; ядущий хлеб сей будет жить вовек»; Иоан.6:51).

Образ хлеба, брошенного в воду, связан с символикой жизненного странствия. Он синонимичен образу странствия колен Израилевых по пустыне в поисках Земли Обетованной - ключевой самоидентифицирующей мифологеме русской эмиграции. Как мы уже упоминали выше, русская эмиграция осознавала свою жизнь «после России» как странствие в поисках Земли Обетованной. В этом плане первое, еще доэмигрантское, путешествие Сорокина в Западную Европу, стало своего рода прологом к долгому эмигрантскому странствию.

Для русской эмиграции образ «отплытия в никуда», в новую жизнь «без России», в поисках Земли Обетованной, во многом связывался с образом пророка Моисея. В частности, А. Аржаковский связывает путь русской эмиграции первой волны с походом 13-ти колен Израилевых, возглавляемых Моисеем, с их движением по пустыне в поисках новой родины [Аржаковский А. Журнал «Путь» (1925-1940). Поколение русских религиозных мыслителей в эмиграции. Киев: Феникс, 2000.]

Движение от космоса к хаосу, от веры - к безверию, от воцерковленности к вероотступничеству совершает в «Дальней дороге» и русский народ, путь которого разделяет автор. Однако впоследствии герой-рассказчик раскаивается в том, что выбрал 
вероотступнический путь «с судьбой и с гуртом», и возвращается к «вере отцов» в эмиграции.

О такой дороге русского народа писал поэт-эмигрант Г.В. Иванов в стихотворении «Несколько поэтов. Достоевский»: «Широка на Соловки дорога, / Где народ, свободе изменивший, / Ищет, в муках, родину и Бога» [Мы жили тогда на планете другой...». Антология поэзии русского зарубежья в 4-х т. Т. 1. М.: Московский рабочий, 1994. С. 37.]Интересно, что в данном случае Соловки - отнюдь не центр русской святости, а русская Голгофа - Соловецкий лагерь особого назначения (СЛОН). До богоборческой Октябрьской революции «дорога на Соловки» подразумевала духовное паломничество, путь к христианским святыням, после революции - это был крёстный путь русского народа, путь в тюрьму, где, через страдание и покаяние, многие узники вновь обретали Бога.

Метафорический концепт «Путь» реализуется в «Дальней дороге» П.А. Сорокина в ряде образов-символов, таких как «Промысел Божий», «духовное преображение / духовный упадок», «духовное восхождение / нисхождение», «странствие духа» и связанных с этим образами метафор. Название автобиографического произведения Сорокина глубоко метафорично: оно отсылает нас не только к жизненному и творческому пути героя-рассказчика, но и к пути самой России. Движение от «Святой Руси» к безбожной и охваченной социальным пожаром «Руси Советской» находится в центре повествования, понимается героем-рассказчиком как нисхождение его родины в ад.

\section{Список литературы:}

1. Аржаковский А. Журнал «Путь» (1925-1940). Поколение русских религиозных мыслителей в эмиграции. Киев: Феникс, 2000.

2. Брюсов В. Стихотворения и поэмы. Библиотека поэта. Большая серия. Ленинград: Советский писатель, 1961. С. 99.

3. Герра Р. «Когда мы в Россию вернемся...» / Р. Герра. - СПб.: Росток, 2010. $668 \mathrm{c}$.

4. Зайцев Б.К. Сердце Авраамия // Зайцев Б. Сборник «Тихие зори». Мюнхен: Издательство Товарищества зарубежных писателей, 1961. С. 86-89.

5. Соколов А.Г. Судьбы русской литературной эмиграции 1920-х годов / А.Г. Соколов. М.: Издательство Московского государственного университета им. М.В. Ломоносова, 1991. - 180 с.

6. Сорокина Л.М. Безумие и беззвучие в романе М.А. Булгакова «Мастер и Маргарита» // Вестник Поморского университета. - 2010. - №2. - С. 43 -49.

7. Тынянов Ю.Н. Промежуток // Тынянов. Ю.Н. Поэтика. История литературы. Кино / Ю.Н. Тынянов. - М.: Искусство, 1977. - С. 185. 